\title{
Effects of a fructose-rich diet and the aldose reductase inhibitor, ONO-2235, on the development of diabetic neuropathy in streptozotocin-treated rats
}

\author{
N. Hotta ${ }^{1}$, H. Kakuta ${ }^{1}$, H. Fukasawa ${ }^{1}$, M. Kimura ${ }^{1}$, N. Koh' ${ }^{1}$, M. Iida ${ }^{2}$, H. Terashima ${ }^{3}$, T. Morimura ${ }^{3}$ and N. Sakamoto \\ ${ }^{1}$ Third Department of Internal Medicine and ${ }^{2}$ First Department of Internal Medicine, Nagoya University School of Medicine, Nagoya and \\ ${ }^{3}$ Bio-Science Department, Research Institute, ONO Pharmaceuticals, Osaka, Japan
}

\begin{abstract}
Summary. Streptozotocin-diabetic rats were maintained on a $72 \%$ fructose diet for 4 weeks and some were treated with an aldose reductase inhibitor (either alrestatin: $0.9 \mathrm{~g} \cdot \mathrm{kg}^{-1} \cdot \mathrm{day}^{-1}$ or ONO-2235: $50 \mathrm{mg} \cdot \mathrm{kg}^{-1} \cdot \mathrm{day}^{-1}$ ). Fructose feeding significantly influenced the development of impaired motor nerve conduction velocity in the diabetic rats and this effect was positively correlated with sorbitol accumulation in the sciatic nerve of diabetic rats maintained on a fructose-rich diet. Treatment with ONO-2235, a new aldose reductase inhibitor, prevented both slowing of motor nerve conduction velocity and elevation of nerve sorbitol concentration. On the other
\end{abstract}

hand, erythrocyte sorbitol levels were significantly correlated to those of the sciatic nerve $(r=0.86, p<0.001)$ and the retina $(r=0.91, p<0.001)$ in these animals. Thus, our findings suggest that increased polyol pathway activity may be related to the pathogenesis of diabetic neuropathy and erythrocyte sorbitol concentrations may prove a useful indicator for the presence of diabetic complications.

Key words. Fructose-rich diet, aldose reductase inhibitor, ONO-2235, diabetic neuropathy, polyol pathway, sorbitol, sciatic nerve, retina, erythrocyte.
Recent studies in animals [1-7], and to some extent in man [8-12], suggest that alterations of polyol pathway activity may play an important role in the development of diabetic neuropathy. However, as yet, there is no definitive evidence. As both genetically selected [13] and streptozotocin-diabetic rats $[2,14]$ maintained on a fructose-rich diet have been shown to develop diabetic angiopathy, it would seem that the fructose model in diabetic rats may provide new support for the role of the polyol pathway in the genesis of diabetic complications [15]. Moreover, sorbitol and fructose accumulation in the tissues of streptozotocin-diabetic rats maintained on a $72 \%$ fructose diet for 4 weeks, was $30 \%$ greater than in those maintained on a $72 \%$ glucose diet for the same period [16]. Thus, it was expected that fructose feeding to diabetic rats would result in the development of diabetic neuropathy, as does galactose feeding $[1,15,17]$.

The aim of the present study was to elucidate the possible role of the polyol pathway in the aetiology of diabetic neuropathy and the beneficial effect of ONO2235 on the prevention of peripheral neuropathy in diabetes mellitus.

\section{Materials and methods}

\section{Animals and experimental protocols}

Diabetes was induced in male Wistar rats (weight $200-250 \mathrm{~g}$ ) by a low dose of streptozotocin ( $40 \mathrm{mg} / \mathrm{kg}$ body weight). A single injection at a level not directly toxic to peripheral nerve was made into the tail vein of rats fasted overnight. The drug was dissolved in saline $(0.15 \mathrm{~mol} / \mathrm{l})$ immediately before injection.

After 2 weeks of streptozotocin administration, the diabetic rats (blood glucose $>20 \mathrm{mmol} / \mathrm{l}$ ) were selected at random and divided into five groups. A control group (group D) had free access to laboratory chow and water without treatment for 4 weeks. The remaining four groups of rats were maintaned on a $72 \%$ fructose-diet for 4 weeks as reported previously $[3,14]$. One of these groups received no further treatment (group DF), whilst the others were treated with aldose reductase inhibitor [alrestatin (group DFA) or ONO-2235 (group DFO)] or insulin (group DFI). Aldose reductase inhibitor was added to the fructose diet. Alrestatin (a gift from Nihon-Kayaku, Tokyo, Japan) was fed as $0.7 \%$ of diet (approximately $0.9 \mathrm{~g} \cdot \mathrm{kg}^{-1} \cdot$ day $^{-1}$ ) and (E)-3-carboxymethyl-5-[(E)-2-methyl-3-phenylpropenylidene] rhodanine (ONO-2235, a gift from Ono Pharmaceuticals, Osaka, Japan) was fed as $0.04 \%$ of the diet (approximately $50 \mathrm{mg} \cdot \mathrm{kg}^{-1} \cdot \mathrm{day}^{-1}$ ). Lente insulin was injected subcutaneously daily for 4 weeks at doses varying from 2 to $6 \mathrm{U}$ according to the levels of glucose and ketone revealed in the urine by the reagent strips of Multistix (Miles-Sankyo, Tokyo, Japan). One group of normal rats was maintained on a $72 \%$ fructose diet for 4 weeks (group CF), whilst a control group (group C) had free access to laboratory chow and water only.

\section{Measurement of motor nerve conduction velocity and analysis}

Motor nerve conduction velocity (MNCV) was measured in the most rapidly conducting fibres of the rat tail nerve supplying the segmental muscle according to the method of Miyoshi and Goto [17]. The rats were kept on a heated pad in a room maintained at $25^{\circ} \mathrm{C}$ to preserve a constant rectal temperature of $37^{\circ} \mathrm{C}$. After intraperitoneal injection of sodium pentobarbital (30-40 $\mathrm{mg} / \mathrm{kg}$ body weight), MNCV was determined using a Neuropak NEM-3102 instrument (Nihon-Koden, Osaka, Japan) at 0,2 and 4 weeks following the initiation of treatment. 
Table 1. Body weight and blood glucose concentrations in rats maintained on specified treatment for 4 weeks

\begin{tabular}{|c|c|c|c|c|}
\hline Animal group & $\begin{array}{l}\text { Group } \\
\text { code }\end{array}$ & Diet & $\begin{array}{l}\text { Body weight } \\
\text { (g) }\end{array}$ & $\begin{array}{l}\text { Blood glucose } \\
(\mathrm{mmol} / 1)\end{array}$ \\
\hline $\begin{array}{l}\text { Normal } \\
\text { control rats }\end{array}$ & $\begin{array}{l}\mathrm{C} \\
\mathrm{CF}\end{array}$ & $\begin{array}{l}\text { Laboratory chow }(n=10) \\
\text { Fructose }(n=12)\end{array}$ & $\begin{array}{l}363 \pm 8 \\
360 \pm 5\end{array}$ & $\begin{array}{l}5.78 \pm 0.16 \\
6.11 \pm 1.02\end{array}$ \\
\hline $\begin{array}{l}\text { Diabetic } \\
\text { control rats }\end{array}$ & $\begin{array}{l}\mathrm{D} \\
\mathrm{DF}\end{array}$ & $\begin{array}{l}\text { Laboratory chow }(n=7) \\
\text { Fructose }(n=8)\end{array}$ & $\begin{array}{l}229 \pm 18^{a, b} \\
219 \pm 9^{a, b}\end{array}$ & $\begin{array}{l}10.00 \pm 1.06^{\mathrm{a}, \mathrm{b}} \\
11.22 \pm 0.56^{\mathrm{a}, \mathrm{b}}\end{array}$ \\
\hline $\begin{array}{l}\text { Treated diabeti } \\
\text { Alrestatin } \\
\text { ONO-2235 } \\
\text { Insulin }\end{array}$ & $\begin{array}{l}\text { DFA } \\
\text { DFO } \\
\text { DFI }\end{array}$ & $\begin{array}{l}\text { Fructose }(n=6) \\
\text { Fructose }(n=7) \\
\text { Fructose }(n=7)\end{array}$ & $\begin{array}{l}245 \pm 32^{\mathrm{a}, \mathrm{b}} \\
233 \pm 12^{\mathrm{a}, \mathrm{b}} \\
280 \pm 7^{\mathrm{a}, \mathrm{b}, \mathrm{c}, \mathrm{d}, \mathrm{e}}\end{array}$ & $\begin{array}{r}9.56 \pm 0.83^{a, b} \\
10.56 \pm 0.56^{a, b} \\
10.50 \pm 0.78^{a, b}\end{array}$ \\
\hline
\end{tabular}

Results are expressed as mean \pm SEM. ${ }^{\mathrm{a}} p<0.001$ versus group C; ${ }^{\mathrm{b}} p<0.001$ versus group CF; ${ }^{\mathrm{c}} p<0.05$ versus group $\mathrm{D} ;{ }^{\mathrm{d}} p<0.001$ versus group DF; ${ }^{\mathrm{e}} p<0.01$ versus group DFO rats

Table 2. Effect of a fructose-rich diet on motor nerve conduction velocity in streptozotocin-diabetic rats

\begin{tabular}{lllll}
\hline Animal group & $\begin{array}{l}\text { Group } \\
\text { code }\end{array}$ & $\begin{array}{l}\text { Motor nerve conduction velocity } \\
\text { (m/s) at: }\end{array}$ \\
\cline { 3 - 5 } & & 0 weeks & 2 weeks & 4 weeks \\
\hline $\begin{array}{l}\text { Normal rats } \\
\text { Untreated } \\
(n=10)\end{array}$ & $\mathrm{C}$ & $29.2 \pm 0.5$ & $32.2 \pm 1.5$ & $35.4 \pm 1.4$ \\
$\begin{array}{l}\text { Fructose-fed } \\
(n=12)\end{array}$ & $\mathrm{CF}$ & $29.4 \pm 0.7$ & $31.8 \pm 1.4$ & $36.0 \pm 0.8$ \\
$\begin{array}{l}\text { Diabetic rats } \\
\text { Untreated } \\
(n=7)\end{array}$ & $\mathrm{D}$ & $27.9 \pm 0.8$ & $28.5 \pm 0.7$ & $32.2 \pm 0.7^{\mathrm{b}, \mathrm{e}}$ \\
$\begin{array}{l}\text { Fructose-fed } \\
(n=8)\end{array}$ & $\mathrm{DF}$ & $27.3 \pm 0.6^{\mathrm{c}, \mathrm{f}}$ & $29.5 \pm 0.7$ & $28.2 \pm 0.2^{\mathrm{a}, \mathrm{d}, \mathrm{g}}$ \\
\hline
\end{tabular}

Results are expressed as mean \pm SEM. ${ }^{\text {a, b, } c} p<0.001,0.01,0.05$ versus group $\mathrm{C}$; d, e, $p<0.001,0.01,0.05$ versus group $\mathrm{CF}$ respectively; ${ }^{\mathrm{g}} p<0.001$ versus group $\mathrm{D}$ rats

At the end of this experimental period, rats were fasted overnight before study. After induction of anaesthesia (sodium pentobarbital $30-40 \mathrm{mg} / \mathrm{kg}$ body weight), blood was drawn from the vena cava inferior, and collected in ice-cold tubes for determination of glucose and sorbitol. The sciatic nerves and retina were removed immediately. The sciatic nerves were removed from the level of the sciatic notch and extending approximately $3 \mathrm{~cm}$ distally. After removal of fat and connective tissues, the nerve was weighed, immediately frozen in liquid nitrogen and stored at $-80^{\circ} \mathrm{C}$ until analysis for glucose and sugar alcohol contents.

To determine glucose, sorbitol and fructose concentrations, the nerves were homogenized in ice-cold $10 \%(\mathrm{wt} / \mathrm{vol}) \mathrm{HClO}_{4}(0.5 \mathrm{ml})$ in a glass-in-glass hand homogenizer (Kinoshita-Rika, Nagoya, Japan) and centrifuged at $1400 \mathrm{~g}$ for $10 \mathrm{~min}$ at $4{ }^{\circ} \mathrm{C}$. The supernatants were neutralized with $2 \mathrm{~N} \mathrm{KOH}$. After centrifugation, glucose [18], sorbitol [19] and fructose [20] were measured enzymatically.

Sorbitol levels in the retina were measured as described above after homogenization in ice-cold $10 \%(\mathrm{wt} / \mathrm{vol}) \mathrm{HClO}_{4}(1.0 \mathrm{ml})$ and centrifugation at $1400 \mathrm{~g}$ for $10 \mathrm{~min}$ at $4{ }^{\circ} \mathrm{C}$. Erythrocyte sorbitol content was measured according to the technique of Malone et al. [21]. Blood glucose was determined using a glucose test kit (New Glucostat, Worthington Biochemicals, Freehold, New Jersey, USA).

\section{Statistical methods}

All results are presented as mean \pm SEM. The significance of differences, were calculated by the Student's t-test.

\section{Results}

The changes in body weight for all groups of rats are shown in Table 1. Body weight and blood glucose levels in normal rats were similar in the fructose-fed group (group $\mathrm{CF}$ ) and the laboratory chow-fed group (group C). The streptozotocin-diabetic rats lost weight significantly, but treatment with aldose reductase inhibitors (groups DFA, DFO) had no effects on weight loss or severity of hyperglycaemia. Differences in blood glucose levels between the insulin-treated diabetic group (group DFI) and the other diabetic groups were of little significance since the insulin dose was varied according to the diabetic condition of individual rats. However, group DFI rats did not lose weight significantly compared with the other groups of diabetic rats.

\section{Effect of a fructose-rich diet and aldose reductase inhibitors on $M N C V$}

The fructose feeding for 4 weeks significantly influenced the development of impaired MNCV in diabetic rats compared with untreated diabetic rats $(28.2 \pm 0.2$ versus $32.2 \pm 0.7 \mathrm{~m} / \mathrm{s}, p<0.001$; Table 2). Sorbitol and fructose concentrations in the sciatic nerves were more markedly elevated in group DF than in group D rats (Table 3), suggesting that the MNCV defect may be related to nerve sorbitol and fructose contents. However, in normal rats, neither MNCV nor the concentrations of nerve glucose, sorbitol or fructose were affected by fructose feeding.

Table 4 shows the effects of aldose reductase inhibitors and insulin on the development of impaired MNCV in diabetic rats maintained on a fructose-rich diet. Animals in groups DFA, DFO, DFI showed a marked improvement in MNCV after 4 weeks, compared with those in group DF, but there were no differences in improvement of MNCV between the three treated diabetic groups. Sorbitol and fructose contents in the sciatic nerve were reduced by $>40 \%$ in groups DFA, DFO, DFI compaired with group DF rats (Table 5). However, since this reduction was only ap- 
Table 3. Sorbitol, fructose and glucose concentrations in the sciatic nerve of normal and streptozotocin-diabetic rats maintained on a fructoserich diet for 4 weeks

\begin{tabular}{|c|c|c|c|c|}
\hline Animal group & $\begin{array}{l}\text { Group } \\
\text { code }\end{array}$ & $\begin{array}{l}\text { Glucose } \\
\text { ( } \mu \mathrm{mol} / \mathrm{g} \text { wet weight })\end{array}$ & $\begin{array}{l}\text { Sorbitol } \\
(\mu \mathrm{mol} / \mathrm{g} \text { wet weight) }\end{array}$ & $\begin{array}{l}\text { Fructose } \\
(\mu \mathrm{mol} / \mathrm{g} \text { wet weight) }\end{array}$ \\
\hline \multicolumn{5}{|l|}{ Normal rats } \\
\hline Fructose-fed $(n=12)$ & $\mathrm{CF}$ & $3.25 \pm 0.24$ & $0.11 \pm 0.02$ & $1.14 \pm 0.09$ \\
\hline \multicolumn{5}{|l|}{ Diabetic rats } \\
\hline Untreated $(n=7)$ & D & $3.97 \pm 0.84$ & $0.26 \pm 0.03^{b, c}$ & $2.67 \pm 0.37^{a, c}$ \\
\hline
\end{tabular}

Results are expressed as mean \pm SEM. a, b $p<0.001,0.02$ versus group $\mathrm{C} ;{ }^{c} p<0.001$ versus group $\mathrm{CF} ;{ }^{\mathrm{d}, \mathrm{e}} p<0.005,0.02$ versus group $\mathrm{D}$ rats respectively

Table 4. Motor nerve conduction velocity in normal and streptozotocin-diabetic rats maintained on a fructose-rich diet during treatment with aldose reductase inhibitors and insulin

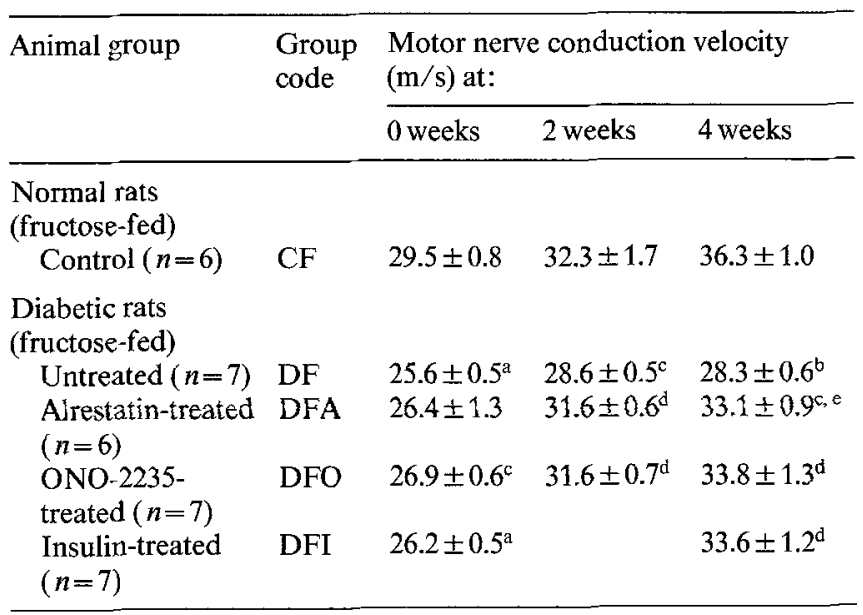

Results are expressed as mean \pm SEM. ${ }^{a, b, c} p<0.005,0.01,0,05$ versus group CF; d e $p<0.005,0.01$ versus group DF rats respectively

proximately $50 \%$, neither of the inhibitors nor insulin at the doses used completely inhibited aldose reductase at the high blood glucose levels of these rats.

Although the increased accumulation of sorbitol in the sciatic nerve in group DF rats was strongly prevented by the treatment of ONO-2235 and insulin, the effects in the sciatic nerve were observed also in both the retina and erythrocytes of group DF rats (Table 5). Erythrocyte sorbitol levels of all experimental animals were significantly correlated with those of the sciatic nerve $(r=0.86, p<0.001)$ and the retina $(r=0.91$, $p<0.001)$.

\section{Discussion}

It is now accepted that early metabolic abnormalities in nerves resulting from chronic insulin deficiency and hyperglycaemia, rather than from vascular changes, heavily influence the development of diabetic neuropathy [22]. However, there are numerous proposals for possible pathogenetic metabolic alterations in nerve disorders in diabetes $[22,23]$.
In the present study, it was revealed that a fructoserich diet fed to diabetic rats could bring about impaired MNCV which could be prevented by treatment with aldose reductase inhibitors. Although ONO-2235, a new aldose reductase inhibitor, prevented both slowing of MNCV and the elevation of nerve sorbitol concentration, both effects were similar to those of alrestatin and insulin treatment. Although the reduction rate of nerve sorbitol content by treatment with either of the aldose reductase inhibitors or insulin was less in the present study $(50-60 \%)$ than in other reports $(70-90 \%)$ [3-7], treatment showed the same improvement of MNCV in our animal models as in these other reports. This low reduction of nerve sorbitol and fructose content by treatment with aldose reductase inhibitors and insulin is explainable by (1) the use of low doses of aldose reductase inhibitors and (2) the direct transport of fructose to the sciatic nerve causing elevated sorbitol and fructose content. In recent experiments with diabetic rats, after 6 months of streptozotocin administration, the animals received ONO-2235 mixed in the food at two different doses $\left(50\right.$ and $\left.100 \mathrm{mg} \cdot \mathrm{kg}^{-1} \cdot \mathrm{day}^{-1}\right)$ for 4 weeks [24]. The MNCV of rats treated with the higher dose was more markedly improved than that of animals treated with the lower dose $(42.2 \pm 0.8$ versus $40.0 \pm 0.7 \mathrm{~m} / \mathrm{s}, p<$ 0.05 ), whilst the MNCV of corresponding untreated diabetic rats was $35.9 \pm 1.0 \mathrm{~m} / \mathrm{s}$. All these changes appeared to be related to nerve sorbitol content (high dose: $1.45 \pm 0.10$; low dose: $1.63 \pm 0.12$; control: $1.89 \pm 0.15 \mu \mathrm{mol} / \mathrm{g}$ wet weight; high dose versus control, $p<0.01$ ). Thus, it was expected that the higher doses of aldose reductase inhibitor administered in the present study would cause a more marked effect on the reduction of nerve sorbitol content. In experiments in vivo, most of the administered fructose was converted rapidly into glucose by the liver and approximately $20 \%$ of the fructose load was not metabolized [25]. The accumulation of sorbitol and fructose in the retina and lens were observed more markedly in diabetic rats maintained on a fructose-rich diet than in those maintained on a glucose-rich diet [16]. The presumed role of the fructose diet in the present study is on the basis of these data $[16,25]$. The increased accumulation of sorbitol and fructose in the diabetic rats maintained on a fruc- 
Table 5. Effect of aldose reductase inhibitors and insulin treatment on sorbitol, fructose and glucose concentrations in the sciatic nerve and on sorbitol concentrations in the retina and erythrocytes of streptozotocin-diabetic rats maintained on a fructose-rich diet for 4 weeks

\begin{tabular}{|c|c|c|c|c|c|c|}
\hline Animal group & $\begin{array}{l}\text { Group } \\
\text { code }\end{array}$ & \multicolumn{3}{|c|}{ Sciatic nerve ( $\mu \mathrm{mol} / \mathrm{g}$ wet weight) } & $\begin{array}{l}\text { Retina } \\
\text { Sorbitol } \\
\text { ( } \mu \text { mol } / \mathrm{g} \text { wet weight })\end{array}$ & $\begin{array}{l}\text { Erythrocytes } \\
\text { Sorbitol } \\
\text { (nmol/g haemoglobin) }\end{array}$ \\
\hline Control $(n=6)$ & $\mathrm{CF}$ & $2.98 \pm 0.18$ & $1.07 \pm 0.07$ & $0.11 \pm 0.02$ & $0.27 \pm 0.10$ & $38.83 \pm 7.79$ \\
\hline \multicolumn{7}{|l|}{ Diabetic rats (fructose-fed) } \\
\hline Untreated $(n=7)$ & DF & $5.48 \pm 0.69^{\mathrm{c}}$ & $5.96 \pm 0.50^{\mathrm{a}}$ & $0.47 \pm 0.04^{\mathrm{a}}$ & $1.15 \pm 0.01^{\mathrm{a}}$ & $220.00 \pm 18.21^{\mathrm{a}}$ \\
\hline ONO-2235-treated $(n=7)$ & $\mathrm{DFO}$ & $4.89 \pm 0.47^{\mathrm{b}}$ & $3.14 \pm 0.69^{d, ~ h ~}$ & $0.25 \pm 0.05^{\mathrm{d}, \mathrm{g}}$ & $0.51 \pm 0.11^{\mathrm{f}}$ & $127.39 \pm 8.97^{\mathrm{a}, \mathrm{f}}$ \\
\hline Insulin-treated $(n=7)$ & DFI & $4.36 \pm 0.53^{\mathrm{e}}$ & $2.44 \pm 0.35^{b, f}$ & $0.22 \pm 0.03^{\mathrm{d}, \mathrm{f}}$ & $0.42 \pm 0.15^{f}$ & $141.16 \pm 9.00^{\mathrm{a}, \mathrm{s}}$ \\
\hline
\end{tabular}

Results are expressed as mean \pm SEM.

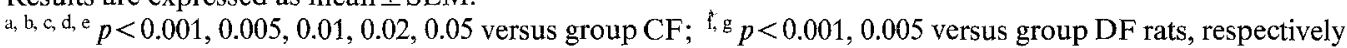

tose-rich diet compared with the untreated diabetic group should accrue from increased polyol pathway activity and hepatic isomerase reaction affecting blood glucose levels. Thus, our findings suggest that the use of aldose reductase inhibitors in animal models has good potential for assessing the role of the polyol pathway in MNCV impairment.

A marked decrease of nerve sorbitol and fructose content in insulin treated diabetic rats was observed despite a small reduction in nerve glucose levels (Table 5). As aldose reductase activity of the polyol pathway is not affected directly by insulin [16, 29], it is likely that the specific activities of several enzymes regulated by insulin are altered and that glucose utilization is diverted to metabolic pathways other than the polyol pathway. In vitro, at physiological glucose concentrations, approximately $3 \%$ of the glucose uptake was utilized for sorbitol and fructose synthesis and this increased to as much as $11 \%$ at $50 \mathrm{mmol} / 1$ glucose concentration [26]. However, extracellular glucose in our study was only approximately $20 \%$ of that quoted in the above reference. Nerve sorbitol and fructose synthesis in insulin-treated diabetic rats may be strongly influenced by even a small reduction of nerve glucose content, as was observed in the present study. Moreover, this could explain why neither MNCV nor nerve sugar alcohol content were affected by fructose feeding in normal rats.

Recent histological studies in diabetic neuropathy have demonstrated enlargement of endoneural space as a cause of increased water content [27]. It might be speculated, for example, that if the excess of sorbitol and fructose within the Schwann cell were to leak into the endoneural space, this would contribute to the osmotic force, leading to swelling of the space as well as to shrinkage of the axon and the Schwann cell [22]. As the accumulation of $1 \mu \mathrm{mol}$ of solute/g wet weight is equivalent to $1 \mathrm{mosmol} / 1$ in osmotic pressure [28], osmotic damage could occur with the accumulation of sorbitol and fructose observed in our study. However, the mechanism by which the polyol pathway hyperactivity influences the pathogenesis of diabetic neuropathy is not yet established. Recently, other investigators focussed on the polyol pathway in conjunction with myo-inositol metabolism in nerves $[6,23,29]$. Thus, peripheral nerve dysfunction in diabetes via polyol pathway hyperactivity may be further complicated by a biochemical mechanism based on the osmotic hypothesis [22, 23, 27].

ONO-2235, has a short circulating half-life $(1 \mathrm{~h}$ in rats and man) compared with that of sorbinil $(4 \mathrm{~h}$ in rats) [30], but the same as that of alrestatin [1]. The dose of ONO-2235 used in this study was equal to that used in diabetic patients treated for a 12-week period, when improvement in both nerve conduction velocity and subjective symptoms, such as pain and numbness, correlated well with reduction of erythrocyte sorbitol content [2]. Therefore, the effects of ONO-2235 in the present study could be partially explained on a pharmacological basis.

On the other hand, it is of clinical interest to know whether a good correlation exists between erythrocyte and tissue sorbitol levels in diabetes-associated complications. In the present study, it was confirmed that erythrocyte sorbitol levels were significantly correlated to those of the sciatic nerve $(r=0.86, p<0.001)$ and the retina $(r=0.91, p<0.001)$ in individual animals. If increased polyol pathway activity is strongly related to the pathogenesis of diabetic complications, our present findings show that erythrocyte sorbitol concentrations may be a useful indicator for the presence of diabetic complications as mentioned by Malone et al. [21].

Acknowledgements. This work was supported in part by Grant No. 548350 from the Scientific Research Council of Japan and Daiwa Health Foundation.

\section{References}

1. Dvornik D, Simard-Duquesne N, Krami M, Sestanj K, Gabbay KH, Kinoshita JH, Varma SD, Merola O (1973) Polyol accumulation in galactosemic and diabetic rats: control by an aldose reductase inhibitor. Science 182: 1146-1148

2. Hotta N, Kakuta H, Kamei I, Kimura M, Fukasawa H, Koh N, Sakamoto N (1982) Effect of fructose-enriched diet and aldose reductase inhibitor in the development of diabetic complications. Diabetes (Suppl 2): $10 \mathrm{~A}$ 
3. Hotta N, Kakuta H, Kamei I, Kimura M, Fukasawa H, Koh N, Sakamoto N, Matsuoka Y, Iida M (1982) The effect of fructose diet on diabetic nerve. In: Goto Y, Horiuchi A, Kogure K (eds) Proceedings of the International Symposium on Diabetic Neuropathy and its Treatment, Tokyo. Excerpta Medica, Amsterdam, International Congress Series 581: 109-113

4. Tomlinson DR, Holmes PR, Mayer JH (1982) Reversal, by treatment with an aldose reductase inhibitor, of impaired axonal transport and motor nerve conduction velocity in experimental diabetes mellitus. Neurosci Lett 31:189-193

5. Yue DK, Hanwell MA, Satchell FM, Turtle JR (1982) The effect of aldose reductase inhibition on motor nerve conduction velocity in diabetic rat. Diabetes 31: 789-794

6. Gillon KRW, Hawthorne JN, Tomlinson DR (1983) Myoinositol and sorbitol metabolism in relation to peripheral nerve function in experimental diabetes in the rat: the effect of aldose reductase inhibition. Diabetologia 25:365-371

7. Kikkawa $R$, Hatanaka I, Yasuda $H$, Kobayashi N, Shigeta $Y$, Terashima H, Morimura T, Tsuboshima M (1983) Effects of a new aldose reductase inhibitor, (E)-3-carboxymethyl-5-[(2E)-methy]3-phenylpropenylidene] thodanine (ONO-2235) on peripheral nerve disorders in streptozotocin-diabetic rats. Diabetologia 24: $290-292$

8. Fugius J, Jameson S (1981) Effects of aldose reductase inhibitor treatment in diabetic polyneuropathy - a clinical and neurophysiological study. J Neurol Neurosurg Psychiatr 44: 991-1001

9. Handelsman DJ, Turtle JR (1981) Clinical trial of an aldose reductase inhibitor in diabetic neuropathy. Diabetes 30: 459-464

10. Hotta N, Kakuta H, Kimura M, Fukasawa H, Koh N, Terashima H, lida M, Sakamoto N (1983) Experimental and clinical trial of aldose reductase inhibitor in diabetic neuropathy. Diabetes (Suppl 2): 98A

11. Jaspan JB, Mafelli R, Herold K, Bartkuf C (1983) Treatment of severely painful diabetic neuropathy with an aldose reductase inhibitor: relief of pain and improved somatic and autonomic nerve function. Lancet 2: 758-762

12. Judzewitsch RG, Jaspan JB, Polonsky KS, Weinberg CR, Halter JB, Halar E, Pfeifer MA, Vukadinovic C, Bernstein L, Schneider M, Liang K-Y, Gabbay KH, Rubenstein AH, Porte Jr D (1983) Aldose reductase inhibition improves nerve conduction velocity in diabetic patients. $\mathrm{N}$ Engl J Med 308: 119-125

13. Cohen AM, Teitelbaum A, Rosenman E (1977) Diabetes induced by a high fructose diet. Metabolism 26:17-24

14. Hotta N, Kakuta H, Kunieda T, Ida A, Tamagawa T, Kojima K, Sakamoto N (1982) Influence of fructose on the development of vascular disease in diabetes. In: Melish JS, Hanna J, Baba S (eds) Proceedings of the Third Symposium on Diabetes Mellitus in Asia and Oceania, Hawaii. Excerpta Medica, Amsterdam, International Congress Series 549: 344-347

15. Gabbay KH (1973) The sorbitol pathway and the complications of diabetes. N Engl J Med 288: 831-836
16. Hotta N, Kakuta H (1981) Pathogenesis of diabetic retinopathy from aspects of retinal metabolism. J Japan Diab Soc 24: $1100-1103$

17. Miyoshi T, Goto I (1973) Serial in vivo determinations of nerve conduction velocity in rat tails: physiological and pathological change. Electroencephalogr Clin Neurophysiol 35: 125-131

18. Bergmeyer HU, Bernt E, Schmidt F, Stock H (1974) D-Glucose. In: Bergmeyer HU (ed) Methods of enzymatic analysis. Academic Press, New York, pp 1196-1201

19. Bergmeyer HU, Gruber W, Gutmann I (1974) D-Sorbitol. In: Bergmeyer HU (ed) Methods of enzymatic analysis. Academic Press, New York, pp 1323-1326

20. Bernt E, Bergmeyer HU (1974) D-Fructose. In: Bergmeyer HU (ed) Methods of enzymatic analysis. Academic Press, New York, pp 1304-1307

21. Malone JI, Knox G, Benford S, Tedesco TA (1980) Red cell sorbitol. An indicator of diabetic control. Diabetes 29: 861-864

22. Clements RS (1979) Diabetic neuropathy: new concepts of its etiology. Diabetes 28: 604-611

23. Greene DA (1983) Metabolic abnormalities in diabetic peripheral nerve: relation to impaired function. Metabolism 32: 118-123

24. Hotta N, Tersahima H, Sakamoto N: Unpublished data

25. Förster H (1974) Comparative metabolism of xylitol, sorbitol, and fructose. In: Sipple HL, McNutt KW (eds) Sugars in nutrition. Academic Press, New York, San Francisco, London, pp 259-280

26. Morrison AD, Clements RS Jr., Travis SB, Oski F, Winegrad AI (1970) Glucose utilization by the polyol pathway in human erythrocytes. Biochem Biophys Res Commum 40: 199-205

27. Jakobsen J (1978) Peripheral nerve in early experimental diabetes: expansion of the endoneural space as a cause of increased water content. Diabetologia 14: 113-119

28. Gabbay KH (1975) Hyperglycemia, polyol metabolism, and complications of diabetes mellitus. Ann Rev Med 26: 521-536

29. Mayer JH, Tomlinson DR (1983) Prevention of defects of axonal transport and nerve conduction velocity by oral administration of myo-inositol or an aldose reductase inhibitor in streptozotocindiabetic rats. Diabetologia 25: 433-438

30. Peterson MJ, Sarges R, Aldinger CE, McDonald DP (1979) CP45,634; a novel aldose reductase inhibitor that inhibits polyol pathway activity in diabetic and galactosemic rats. Metabolism 28 (Suppl 1): 456-461

Received: 17 April 1984

and in revised form: 27 December 1984

Dr. Nigishi Hotta

The Third Department of Internal Medicine

Nagoya University School of Medicine

65 Tsuruma-cho, Showa-ku

Nagoya 466 Japan 